\title{
Innovation a Key Towards Employee Engagement
}

\author{
Shailashri V. T. ${ }^{1}$, \& Sureka Shenoy ${ }^{2}$ \\ ${ }^{1}$ Srinivas Institute of Management Studies, Pandeshwar, Mangalore. \\ ${ }^{1}$ Research Scholar, Rayalaseema University, Kurnool India. \\ ${ }^{2}$ Faculty, Srinivas Institute of Management Studies, Pandeshwar, Mangalore. \\ E-Mail: shailavt@yahoo.co.in
}

Type of the Paper: Research Paper.

Type of Review: Peer Reviewed.

Indexed in: OpenAIRE.

DOI: http://dx.doi.org/10.5281/zenodo.582291.

Google Scholar Citation: IJMTS

\section{How to Cite this Paper:}

Shailashri, V. T., Sureka Shenoy. (2016). Innovation a Key Towards Employee Engagement. International Journal of Management, Technology, and Social Sciences (IJMTS), 1(1), 43-47.

DOI: http://dx.doi.org/10.5281/zenodo.582291.

International Journal of Management, Technology, and Social Sciences (IJMTS)

A Refereed International Journal of Srinivas University, India.

(C)With Authors.

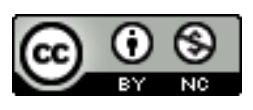

This work is licensed under a Creative Commons Attribution-Non Commercial 4.0 International License subject to proper citation to the publication source of the work.

Disclaimer: The scholarly papers as reviewed and published by the Srinivas Publications (S.P.), India are the views and opinions of their respective authors and are not the views or opinions of the SP. The SP disclaims of any harm or loss caused due to the published content to any party. 


\title{
Innovation a Key Towards Employee Engagement
}

\author{
Shailashri V. T. ${ }^{1}$, \& Sureka Shenoy ${ }^{2}$ \\ ${ }^{1}$ Srinivas Institute of Management Studies, Pandeshwar, Mangalore. \\ ${ }^{1}$ Research Scholar, Rayalaseema University, Kurnool India. \\ ${ }^{2}$ Faculty, Srinivas Institute of Management Studies, Pandeshwar, Mangalore. \\ E-Mail: shailavt@yahoo.co.in
}

\begin{abstract}
Every company wants to succeed in capturing the market and maximizing the profit. With the changes in technology and increase in globalization the world has become a village which leads to high competition and complexity in performance of work. If an organization has to sustain in business they need to change according to times and become proactive. To meet the pace of change in the society the organization should create a atmosphere of innovation in the organization. Innovation comes when there is freedom of thought, and constant encouragement from the top management. As companies are not only competing with domestic companies but with companies all over the world, this is when innovation is needed in a company. How can a company be different from others? Innovation can only be achieved when there are talented human resource and good $\mathrm{H}$ R practices in the company. The HR practices of the company should foster better thinking and involvement every individual in the organization. Innovation in companies is through talented minds in the company. Company has to acquire, develop and retain these people. When individuals get opportunities to innovate they tend to be engaged in the organization. Employee engagement is a key driving factor to the success of any organization. This paper is a case study of the Tata consultancy services TCS. Secondary data is used to identify how TCS manages to retain and engage the best talented workforce. The HRM practices of TCS are understood in depth and a linkage between HR practices and innovative talented and employee engagement is drawn.
\end{abstract}

Keywords: HRM Practices, Innovation, Talented employees, Employee engagement, Case study, TCS.

\section{INTRODUCTION :}

Innovation is everything in a company. For a company to sustain in the market it has to be innovative. India accepted LPG in the year 1991. From that time foreign companies have entered the Indian market. The domestic companies had to compete with foreign countries [1]. With this it also led to development in technology in the country. With all these things human resource became a vital part of a company. Innovations made companies stay in the market. This innovation can only be achieved through people. This paper presents on how innovation can be achieved through people. This also makes people engaged. This study is connected with the case of TCS and secondary data is used.

\section{OBJECTIVES :}

The objective of this paper is to see how human resource practices in a company are connected to innovative people. In this topic we use TCS case to go through with the paper.

\section{METHODOLOGY :}

The paper is based on the secondary data available through published report, case studies and the literature available website, thus it is a purely secondary data based paper which can be a further supported by primary data desired to be collected. Human resource management practices encourage innovation in companies technology has brought about drastic changes. This has led to innovation. This started from the industrial revolution in 1956. In the beginning it was observed that 
employees were considered as a group but with the advent of globalization the importance of each employee has been seen. It has led to developed employee relation management where by each employee has a significant role in the organization [2]. Employees playing a significant role in the organization give them a sense of pride and it leads to innovations in the company. These changes have also brought changes in HR function which is a motivation for innovations.

\section{HR FUNCTIONS REVIEWED :}

The paper seeks to examine the HR practices of TCS with special focus on HR functions and practices and how they help in innovation in the company. As innovations can only be achieved through people. The purpose is see how these practices are used to achieve innovation through people in TCS [3-4].

(1) HR planning:

Human resource planning is the first step in acquiring manpower to the company. In performing these tasks present and future requirements have to be kept in mind. In HR planning there are things to be considered.

- Technology advances

As technology continually changes, the company has to consider to the type of manpower they need.Also how will these manpower help to bring other innovation in the company [5].

- Managing changes

Employee relations management has evolved to bring about the significance of human resource in the organization. In planning for human resource the company should see it goes with this change for innovation.

(2) Recruitment and selection:

After the company has planned for the human resource, the next step is recruitment and selection of the candidates. Companies have neglected the traditional ways of recruitment and selection. Online application, online interviews through skype and other applications have made their way in the present day. Personal interviews are done mostly to discuss salary packages. Online recruitment features and selection help to bring innovations to the company .Recruitment and selection can be affected by the following

- Location of diverse talents

As companies require talented minds for their progress location of these diverse talents can be a problem.

Technology has removed this barrier as recruitment and selection is done online.This help to attain innovative talents.

(3) Training and development:

In the training process the employees are made familiar with the job they are going to perform. It is imbibing an individual with the required skills, knowledge and attitudes so as to fit in a job .Development is usually done for succession planning in the company. With technology, training has been made easier.The company uses technology for training .Online training is used by the company to a great extent .With the use of apps adequate learning at home, alignment with business objectives is progressing .These type of training have developed through innovations in technology. These will motivate the new joiners to give their best and to bring out new innovations. The main innovations seen in training are

- Method of training

Training in the recent days has become more technological base .Example; use of mobile for training and learning at home .The efficiency of training is also measured at every step of the training process.

(4) Performance appraisal

Companies have shifted from standardized work and job evaluation to determine the wage structure .Performance has played a significant role in today's organization. Performance appraisal is very essential for a company. Performance appraisal is not only done to appraise present potentials but also to find out the new potential which can be used for future succession planning [6]. This is an innovation of employee performance appraisal. With this innovation performance appraisal is

(a) Done to appraise the actual performance of the employee

(b) Appraisal is done but not only to determine present potential but also future potentials which could be used for succession planning

(c) A track is kept to observe if the appraisal is effective and if any diversion in employee behaviour

(5) Retention:

In the earlier days it was observed that employees are only motivated through monetary incentives technology has changed 
his rituals employee are not only motivated by monetary incentives but also other benefits. Employer needs more than money to retain an employee [7-8].

In this generation employees are motivated by promotion, sense of recognition, status with pride and an opportunity for further innovations [9]. These motivate company to be innovative on how to retain the best talents in the organization [10]. On this background we now switch over to a case study of human recourse practices in TCS which help in innovations.

Tata Consultancy Services Limited (TCS) software services and consulting company headquartered in Mumbai, India. It is the largest provider of information technology and business process outsourcing services. It is part of one of India's largest and oldest conglomerates, the group TATA. One of TCS' first assignments was to provide punch card services to a sister concern, Tata Steel (then TISCO). It later bagged the country's first software project, the Inter-Branch Reconciliation System (IBRS) for the Central Bank of India [11-13]. TCS have a standard set of practices for maintenance of its HR practices. It is closely linked with the business strategy by planning it according to the structure of the company through the support given by innovative HR practices. Throughout the European countries, it is considered as the best employer with the lowest attrition rate of $9.9 \%$. The company is known for the overall development imparted to its employees which also offers multi-lingual training concepts.

Human resource is a vital function in a company, and with best HR practices employees are motivated, which leads to innovations through employees. This can be connected to the case study of TCS.

- Employment and Job Security

TCS is a good base to work for, especially for fresher's because they are given good opportunities under comfortable cosy environment. Working in TCS feels like working in a government organization because there is high job security. The companies lower turnover rate and career development programs encourages its employees. With a sense of security and a career development, this builds morale among the employees and motivates them for new innovations.
- Selective Hiring

Planning for human resource is the most important task to be done for selecting the best candidate among many applicants .TCS company recruitment process is best in hiring policy which include mix of fresh and experience candidate. This is done so as to acquire best talent to the company. Fresh candidates and experience candidate are recruited in the company so as to bring new ideas and also modify the old ones. With this innovation has a very high chance to occur in the organization the company also uses innovative ways for recruitment such as online recruitment outsourcing from consultants and former employees.

- Team Building

TCS encourages team work in the company. Diversity of people from different places helps in bringing about new ideas to the company hence innovation through people.

The company encourages open door policy which is good in motivating employee in bringing out their ideas.

- High pay is also another factor which contributes to company's performance.

TCS Company is the best employer who has a structure of composition having only 5\% respect on seniority. An employee performing good will be motivated to increase his or her productivity as the company rewards according to performance .TCS also assigns task to teams and the teams can decide their pay structure .TCS uses EVA model(economic value added) to measure performance and bonus focused on the goal to align people to the mission of their company.

- Extensive training

TCS provides training immediately on the first day of joining the organization and continues for a period of three months. Training is given throughout the entire period of working in the company. Training is also imparted to employees when ever new technologies or new platforms are introduced at any point of time. Different kinds of training are provided example Initial Learning Program, Leadership Development program and Workplace Learning. With all these kinds of training in the company it helps employees be familiar with the changing world and how to use these advanced technology for further innovation. TCS has proved to be one of the best in the 
country and managed to imbibe in $\mathrm{HR}$ a practice which helps to nurture talents and bring about innovations. Innovations in a company come from employees but these employees cannot bring out these potential unless and until they are well motivated.

\section{CONCLUSION :}

From the above case we can see how innovation in companies is through people. The people are the man power of the organization. These people are crucial part of the organization without them organization has no meaning

\section{REFERENCES :}

[1] Bassi, L. J., \& Van Buren, M. E. (1998). The 1998 ASTD state of the industry report. Training \& Development, 52(1), 21-44.

[2] Bostrom, R. P., Olfman, L., \& Sein, M. K. (1993). Learning styles and end-user training: A first step. MiS Quarterly, 118120.

[3] Bruen, C., \& Conlan, O. (2002). Adaptive ICT Support for learning Styles-A Development Framework for re-useable learning resources for different learning styles \& requirements. In ITTE Ann. Conf. Assoc. Inf. Tech. Teach. Edu.

[4] Canavan, J. (2004). Personalised $e$ learning through learning style aware adaptive systems (Doctoral dissertation, University of Dublin).

[5] Ryan, M. (1995). Human resource management and the politics of knowledge: linking the essential knowledge base of the organization to strategic decision making. Leadership \& Organization Development Journal, 16(5), 3-10.

[6] Sackmann, S. A. (1992). Culture and subcultures: An analysis of organizational knowledge. Administrative science quarterly, 140-161.

[7] En.wikipedia.org/wiki/talent management

[8] www.tcs.com

[9] ibscdc.org/Case_ Studies/HRM/ HRM 0027A.htm.
[10] Handley, Janet (2012) Talent Management: the construction of talent. Working paper. University of Huddersfield, Huddersfield. (Unpublished) at http:// eprints.hud.ac.uk/1486/

[11] www.ddiworld.com/9bestpractices-tm

[12] Rath, N., Rath, M. S., \& GIFT, B. (2014). TALENT MANAGEMENT IN TCS. Business and Enterprises Applications, 90 .

[13] http://en.m.wikipedia.org/ wiki/ Tata_Co nsultancy_Services. 